\title{
Statyba
}

\section{THE BACKGROUND REQUIREMENTS FOR BUILDING HEAT LOSSES}

\section{Stankevičius \&J. Karbauskaitė}

To cite this article: V. Stankevičius \& J. Karbauskaite (1998) THE BACKGROUND REQUIREMENTS FOR BUILDING HEAT LOSSES, Statyba, 4:3, 185-190, DOI: 10.1080/13921525.1998.10531402

To link to this article: https://doi.org/10.1080/13921525.1998.10531402

曲 Published online: 26 Jul 2012.

Submit your article to this journal

III Article views: 46 


\title{
THE BACKGROUND REQUIREMENTS FOR BUILDING HEAT LOSSES
}

\author{
V. Stankevičius, J. Karbauskaitė
}

\section{Introduction}

Lithuania today experiences a rapid process of cooperation with the structures of European Community. New joint ventures with foreign partners have been established, and a lot of building materials are imported. We ought to keep to the ISO and CEN standards. For this reason a new edition of the Lithuanian Building Code "Thermal Technique of Building Elements" has been compiled with the participation of Mr. C.M.Hector (Swensk Byggledning $\mathrm{AB}$, Sweden), and Dr. E.Jogioja ("Jogioja", Estonia). The aim of the new Building Code is to determine thermal requirements for properties of building materials, building elements, and finally for whole buildings, providing the main accepted calculation methods.

\section{Description}

The Building Code comprises the following points:

- general requirements,

- thermal requirements for newly designed buildings,

- requirements for renovated buildings,

- estimation of heat conductivity of building materials,

- calculation methods of heat transmittance designed values for building elements.

The most important points of the document under discussion are stated further.

\subsection{Required heat transmission coefficients of build- ing enclosures, $U,\left(W / \mathbf{m}^{2} \cdot \mathbf{K}\right)$}

The energy consumption used for the production of a building element and for heat transmission through it during the pay-back of building insulation system should be considered as a criterion for heat insulation requirements in buildings. The dependencies of energy consumption determined for a number of the most popular building materials in Lithuania are presented in Fig 1. The original data of energy consumption for material production in Lithuanian building industry during 1985-91 have been used. The energy consumption for heating is determined with regard to the heat transmission through the building elements, outdoor and indoor average climate data in Lithuania and effectiveness of heating equipment. The required values for basic building elements have been established by the analysis of the collected data and are as follows:

Roofs and ceilings. Optimum value of heat transmission coefficient for roofs is near 0,18 $\mathrm{W} /\left(\mathrm{m}^{2} \cdot \mathrm{K}\right)$. Energy consumption due to the production of materials is $40-100 \mathrm{~kg}$ of reference fuel (reference fuel $\mathbf{R F}$ has worth of $8100 \mathrm{kWh} / \mathrm{kg}$ ) for installation of $1 \mathrm{~m}^{2}$ various roof construction at heat transmission coefficient value mentioned above. Energy consumption on building site is $3-5 \mathrm{~kg} \mathrm{RF} / \mathrm{m}^{2}$. Total energy consumption including heating for ten years at indoor temperature of $20{ }^{\circ} \mathrm{C}$ is equal to $180-260 \mathrm{~kg} \mathrm{RF} / \mathrm{m}^{2}$. Total energy consumption is decreased insignificantly at further decrease of heat transmission coefficient because of considerable excess of materials used.

The least energy consumption has been observed for the roofs of sheet construction. The roof constructions with expanded clay pane background have the largest energy consumption, the ones of reinforced concrete panes with voids or edges are a little better.

Energy consumption on the building site is near $10 \%$ of the amount used for producing materials.

The labour consumption for manufacturing materials does not change considerably with various 


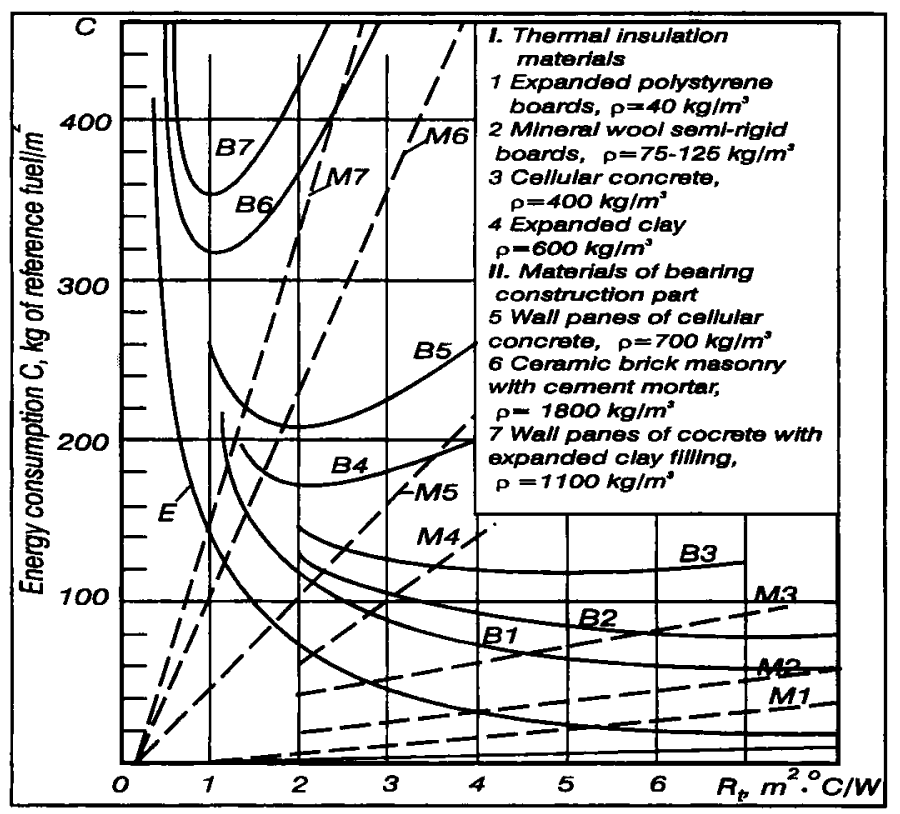

Fig 1. The dependence of energy consumption C, [Energy consumption for heating $E$ during 10 years of service, energy consumption for production of materials $M$ and total energy consumption $B(M+E)$ ], due to the total thermal resistance $R_{t}, \mathrm{~kg}$ of $R F / \mathrm{m}^{2}$ of a building element

construction types. It takes 1-2 labour days for $1 \mathrm{~m}^{2}$ of roof construction. Labour consumption on the building site takes 3-5 days for $1 \mathrm{~m}^{2}$ of roof construction. The difference in labour consumption is about one labour day at the decrease of heat transmission coefficient from $0,5 \mathrm{~W} /\left(\mathrm{m}^{2} \cdot \mathrm{K}\right)$ to $0,25 \mathrm{~W} /\left(\mathrm{m}^{2} \cdot \mathrm{K}\right)$ when various construction types are compared. At the same time the change of total energy consumption can be decreased from 300 to $200 \mathrm{~kg} \mathrm{RF} / \mathrm{m}^{2}$. This observation has shown that the energy consumption can serve as a background for limiting heat transmission value of a building element at a certain level of production and living standard.

Then, for roofs, optimal value of heat transmission coefficient is $0,18 \mathrm{~W} /\left(\mathrm{m}^{2} \cdot \mathrm{K}\right)$ and it is seen as normative at this period of Lithuanian development.

External walls. Optimal value of heat transmission coefficient is $0,26 \mathrm{~W} /\left(\mathrm{m}^{2} \cdot \mathrm{K}\right)$. Then energy consumption due to production of materials varies from 40 to $125 \mathrm{~kg} \mathrm{RF}$. The largest energy consumption is for expanded clay concrete panes. Energy consumption on the building site is near $5 \mathrm{~kg} \mathrm{RF} / \mathrm{m}^{2}$ for most considered wall types. Total energy consumption takes $100-250 \mathrm{~kg} \mathrm{RF} / \mathrm{m}^{2}$ at the above-mentioned value of heat transmission coefficient.

Labour consumption due to material production is $1,2-3,5$ days $/ \mathrm{m}^{2}$. The walls of three layers with heat insulation inside have the least labour consumption, 1,2- 1,5 days $/ \mathrm{m}^{2}$, the masonry takes maximum values with 4-6 labour days $/ \mathrm{m}^{2}$ on the building site. Total labour consumption for external walls then is $3-7,5$ days $/ \mathrm{m}^{2}$.

The heat transmission coefficients in regard to the destination of buildings should be at the minimal energy consumption for:

dwellings (indoor temperature $\left.\mathrm{t}_{\mathrm{i}}=20^{\circ} \mathrm{C}\right)-0,26 \mathrm{~W} /\left(\mathrm{m}^{2} \cdot \mathrm{K}\right)$; public buildings (average $\mathrm{t}_{\mathrm{i}}=12 . .16^{\circ} \mathrm{C}$ ) $-0,30 \mathrm{~W} /\left(\mathrm{m}^{2} \cdot \mathrm{K}\right.$ ); industrial buildings (average $\mathrm{t}_{\mathrm{i}}=5 . .12^{\circ} \mathrm{C}$ ) $-0,30 \mathrm{~W} /\left(\mathrm{m}^{2} \cdot \mathrm{K}\right.$ ).

\subsection{Required specific building heat losses due to heat} transmission through building elements, $\mathbf{H}_{T}$, $\left(\mathbf{W} / \mathbf{m}^{2} \cdot \mathbf{K}\right)$

In the existing Building Code RSN 143-92 "Thermal Technique of Building Elements" [1] the required values of heat transmission coefficients have been determined in the way mentioned above and could be corrected in regard to the construction type and indoor air temperature. They are sufficiently high, but there are certain exceptions, caused by the former poor building industry heritage, eg, when the correction factor for large external wall panes with thermal bridges is 1,8 , and when requirements for ceilings over crawlspaces and basements are sufficiently decreased. 
The heat losses in a building depend on the values of heat transmission coefficients as well as configuration of building. It is reasonable to establish requirements for buildings to restrict the heat losses in them. In accordance with the new ISO and EN documents the new Lithuanian Building Code has been prepared by the staff of Institute of Architecture and Construction in cooperation with C.M.Hector (Sweden) and Dr.E.Jogioja (Estonia). The heat transmission coefficients required could be corrected according to the indoor air temperature. The values of heat transmission coefficient for a separate enclosure could be selected by designer, but not larger than the permissible ones, based on hygienic requirements. At the same time the specific heat losses of a building could not exceed the required value.

Specific heat losses of a building $\mathrm{H}_{\mathrm{T}}$ are determined by the following expression [2]:

$$
H_{T}=\Sigma A_{i} \cdot U_{i}+\Sigma d_{i} \cdot \Psi_{i}, \quad \mathbf{W} / \mathbf{K},
$$

where $A_{i}$ - area of a building element, $\mathrm{m}^{2} ; U_{i}$ - heat transmission coefficient of considered building element, $\mathrm{W} / \mathrm{m}^{2} \cdot \mathrm{K} ; l_{i}$ - length of a linear thermal bridge, $\mathrm{m} ; \Psi_{i}$ - correction factor of a linear thermal bridge, $\mathrm{W} /(\mathrm{m} \cdot \mathrm{K})$.

Required specific heat losses of a building $\mathbf{H}_{\mathrm{TN}}$ are determined by this expression:

$$
H_{T N}=\Sigma A_{i} \cdot U_{R N i}+\Sigma l_{i} \cdot \Psi_{R N i}, \quad \mathrm{~W} / \mathrm{K},
$$

where $U_{R N i}$ - required heat transmission coefficient of considered building element, $\mathrm{W} / \mathrm{m}^{2} \cdot \mathrm{K} ; \Psi_{R N i}$ - required correction factor of a linear thermal bridge, $\mathrm{W} / \mathrm{m} \cdot \mathrm{K}$.

Limited specific heat losses and hygienic conditions to avoid "sick building syndrome" become the main requirement to be fulfilled according to a new document. General requirements for specific heat losses in buildings are determined in regard of building destination: dwelling houses, industrial buildings, public buildings and offices.

Specific heat losses due exclusively to heat transmission through enclosures $\mathbf{H}_{\mathbf{T}}$ are limited in dwelling houses (the values are shown in Table 1 , and required $\mathbf{U}$-values to be used in Table 2).

A building designed with $\mathrm{U}$-values of enclosures not exceeding regular required $\mathbf{U}_{\mathbf{R N}}$ values (Table 2) is considered to meet requirements given in Table 1.
Table 1. Required specific heat losses $\mathbf{H}_{\mathrm{TN}}$ in dwelling houses, W/K

\begin{tabular}{|c|l|c|c|}
\hline No & \multicolumn{1}{|c|}{ Description } & $\begin{array}{c}\text { Total } \\
\text { heated } \\
\text { area } \mathbf{A}_{\mathbf{s}}, \\
\mathbf{m}^{\mathbf{2}}\end{array}$ & $\begin{array}{c}\text { Specific } \\
\text { building } \\
\text { heat loss, } \\
\mathbf{H}_{\mathbf{T N}}, \mathbf{W} / \mathbf{K}\end{array}$ \\
\hline $\mathbf{1}$ & $\begin{array}{l}\text { One-storey family } \\
\text { houses }\end{array}$ & $\begin{array}{c}60 \\
120\end{array}$ & $\begin{array}{c}95 \\
195\end{array}$ \\
\hline $\mathbf{2}$ & One-two storey, incl. & 100 & 130 \\
& mansard, family houses & 250 & 330 \\
\hline $\mathbf{3}$ & One-two storey, incl. & 180 & 220 \\
& mansard, family houses & 400 & 490 \\
\hline $\mathbf{4}$ & Two-storey blocked & 250 & 275 \\
& houses & 550 & 610 \\
\hline $\mathbf{5}$ & 3-4 storey apartment & 500 & 470 \\
& houses & 1800 & 1670 \\
\hline $\mathbf{6}$ & 5 storey apartment & 1500 & 1320 \\
& houses & 4000 & 3500 \\
\hline 7 & 9-12 storey tower shape & 2500 & 2050 \\
& apartment houses & 5000 & 4100 \\
\hline $\mathbf{8}$ & Large houses of various & $>5000$ & $0.7 \mathbf{A}_{\mathbf{s}}$ \\
& height (5-12 st.) and & & \\
\hline & complicated shape & & \\
\hline
\end{tabular}

Note. Requirements of specific heat loss $\mathrm{H}_{\mathrm{T}}$ for buildings in the middle of $A_{s}$ range is determined by the way of interpolation.

Specific heat losses including ventilation and heat gains $\mathbf{H}$ for public, industrial buildings and offices should not exceed the values $\mathbf{H}_{\mathbf{N}}$, which can be achieved using the regular normative $\mathbf{U}_{\mathbf{R N}}$-values of all enclosures. The normative $\mathbf{U}_{\mathbf{R N}}$-values are presented in Tables 3 and 4.

The $\mathbf{U}$-values of all building enclosures should not exceed the corresponding maximum normative $\mathbf{U}_{\mathbf{L N}}$ values, given in the same tables.

Table 2. Required values for heat transmittance coefficient $\mathrm{U}, \mathrm{W} /\left(\mathrm{m}^{2} \cdot \mathrm{K}\right)$ and correction factor of linear thermal bridge $\Psi, \mathrm{W} /(\mathrm{m} \cdot \mathrm{K})$ in dwelling houses

\begin{tabular}{|l|c|c|}
\hline \multicolumn{1}{|c|}{ Type of enclosure } & $\begin{array}{c}\text { Regular norma- } \\
\text { tive value } \mathbf{U}_{\mathbf{R N}}\end{array}$ & $\begin{array}{c}\text { Max. normative } \\
\text { value } \mathbf{U}_{\mathbf{L N}}\end{array}$ \\
\hline Roofs & $0,18 \cdot \kappa$ & $0,25 \cdot \kappa$ \\
\hline Floor on the ground & $0,18 \cdot \kappa$ & $0,25 \cdot \kappa$ \\
\hline Walls & $0,26 \cdot \kappa$ & $0,35 \cdot \kappa$ \\
\hline $\begin{array}{l}\text { Windows, doors and } \\
\text { gates }\end{array}$ & $1, .9 \cdot \kappa$ & 2,5 \\
\hline Linear thermal bridge & $\Psi_{\mathrm{RN}} \leq 0,18 \cdot \kappa$ & $\Psi_{\mathrm{MN}} \leq 0,25 \cdot \kappa$ \\
\hline
\end{tabular}


Table 3. Required values for heat transmittance coefficient $\mathrm{U}, \mathrm{W} /\left(\mathrm{m}^{2} \cdot \mathrm{K}\right)$ and correction factor of linear thermal bridge $\Psi, \mathrm{W} /(\mathrm{m} \cdot \mathrm{K})$ in public buildings and offices

\begin{tabular}{|l|c|c|}
\hline \multicolumn{1}{|c|}{$\begin{array}{c}\text { Type of enclo- } \\
\text { sure }\end{array}$} & $\begin{array}{c}\text { Regular normative } \\
\text { value } \mathbf{U}_{\mathbf{R N}}\end{array}$ & $\begin{array}{c}\text { Max. normative } \\
\text { value } \mathbf{U}_{\mathbf{L N}}\end{array}$ \\
\hline Roofs & $0,2 \cdot \kappa$ & $0,25 \cdot \kappa$ \\
\hline $\begin{array}{l}\text { Floor on the } \\
\text { ground }\end{array}$ & $\mathbf{0 , 3 \cdot \kappa}$ & $0,4 \cdot \kappa$ \\
\hline Walls & $\mathbf{0 , 3 0 \cdot \kappa}$ & 0,40 \\
\hline $\begin{array}{l}\text { Windows, doors } \\
\text { and gates }\end{array}$ & 1,9 & 2,5 \\
\hline $\begin{array}{l}\text { Linear thermal } \\
\text { bridge }\end{array}$ & $\Psi_{\mathbf{R N}} \leq 0,20 \cdot \kappa$ & $\Psi_{\mathbf{L N}} \leq 0,25$ \\
\hline
\end{tabular}

Table 4. Required values for heat transmittance coefficient $\mathrm{U}, \mathrm{W} /\left(\mathrm{m}^{2} \cdot \mathrm{K}\right)$ and correction factor of linear thermal bridge $\psi, \mathrm{W} /(\mathrm{m} \cdot \mathrm{K})$ in industrial buildings

\begin{tabular}{|l|c|c|}
\hline \multicolumn{1}{|c|}{$\begin{array}{c}\text { Type of enclo- } \\
\text { sure }\end{array}$} & $\begin{array}{c}\text { Regular normative } \\
\text { value } \mathbf{U}_{\mathbf{R N}}\end{array}$ & $\begin{array}{c}\text { Max. normative } \\
\text { value } \mathbf{U}_{\mathbf{L N}}\end{array}$ \\
\hline Roofs & $0,25 \cdot \kappa$ & $0,35 \cdot \kappa$ \\
\hline $\begin{array}{l}\text { Floor on the } \\
\text { ground }\end{array}$ & $0,40 \cdot \kappa$ & 0,5 \\
\hline Walls & $0,40 \cdot \kappa$ & 0,8 \\
\hline $\begin{array}{l}\text { Windows, doors } \\
\text { and gates }\end{array}$ & $1,9 \cdot \kappa$ & 2,5 \\
\hline $\begin{array}{l}\text { Linear thermal } \\
\text { bridge }\end{array}$ & $\Psi_{\mathbf{R N}} \leq 0,25 \cdot \kappa$ & $\Psi_{\mathbf{L N}} \leq 0,35 \cdot \kappa$ \\
\hline
\end{tabular}

in all the tables :

$$
\kappa=20 /\left(\Theta_{i}-\Theta_{e}\right)
$$

where $\Theta_{i}$ - internal control zone design mean temperature, ${ }^{\circ} \mathrm{C}$, usually equal to $20^{\circ} \mathrm{C}, \Theta_{e}$ - mean external temperature during heating season, ${ }^{\circ} \mathrm{C}$, it can be assumed to be $0{ }^{\circ} \mathrm{C}$ for all the country, or design temperature in adjacent space.

2.3. Required heat transmission coefficients for building enclosures, $U,\left(W / \mathbf{m}^{2} \cdot K\right)$ and specific heat losses in renovated buildings, determination of optimal values

New premises or annexes of renovated (overhauled) buildings must fulfil the corresponding requirements on specific heat losses $\mathbf{H}_{\mathbf{T}}$. With the change of separate enclosures, heat transmittance coefficient $\mathbf{U}$ and correction factor for linear thermal transmittance of thermal bridges $\Psi$ of a considered enclosure must not exceed the regular normative val- ues presented in Tables 2, 3 or 4, if possible. The thermal resistance value of additional insulation $R$, $\left(\mathrm{m}^{2} \cdot \mathrm{K} / \mathrm{W}\right)$, for enclosures will be determined according to the pay-back period of maintenance costs.

The most correct way for the determination of optimal design thermal properties is to increase insulation thickness up to such level where the expenses for energy consumption related to heating during the pay-back period of insulation system will be less than the price of considered insulation system, that is, the total costs TC will be the least, as it is shown in Fig 2 .

Methodologically the evaluation of the optimal thickness is clearer. This task is very difficult to carry out practically, as there must be considered the forecast of the development of heat prices, bank interest in giving loans and some other important factors, which seem to be dependent not only on economical state in Lithuania. The calculation method considers the mentioned quantities and it ought to be used in the renovation processes. The draft of EN standard Thermal Insulation of Building Components and Equipment Part 2: Calculation of Optimum Economical Thickness of Insulating Layers is used as the basis [3].

The general case for determination of optimum economical thermal resistance value of a building component and separate case for direct determination of insulation thickness according to the least total costs TC during economical service period at certain time $\mathbf{A D}$ are considered.

The least value ATC is established for some different values of thermal resistance $\mathbf{R}_{\boldsymbol{t}}$, if insulation price is not in the rectilinear dependence on thermal resistance value, $\mathrm{Lt} /\left(\mathrm{m}^{2} \cdot \mathrm{a}\right)$ :

$$
A T C=A H C+A J=U \cdot \Delta \Theta \cdot t \cdot E+B \cdot J,
$$

where $A H C$ - annual heating costs, $\mathrm{Lt} /\left(\mathrm{m}^{2} \cdot \mathrm{a}\right) ; A J$ annual price of investments (investments divided by economical service life), $\mathrm{Lt} /\left(\mathrm{m}^{2} \cdot \mathrm{a}\right) ; U$ - thermal transmission coefficient of a building element, $\mathrm{W} /\left(\mathrm{m}^{2} \cdot \mathrm{K}\right)$, $\Delta \Theta$ - average during heating season indoor and outdoor temperature difference at the building element, $\mathrm{K} ; t$ - average duration of heating season, h; $E$ - energy price, $\mathrm{Lt} / \mathrm{kWh} ; J$ - investments required, $\mathrm{Lt}$.

Capital service factor, including the investment related annuity of interest life (of deposit or loan) and service is determined according to the following expression: 


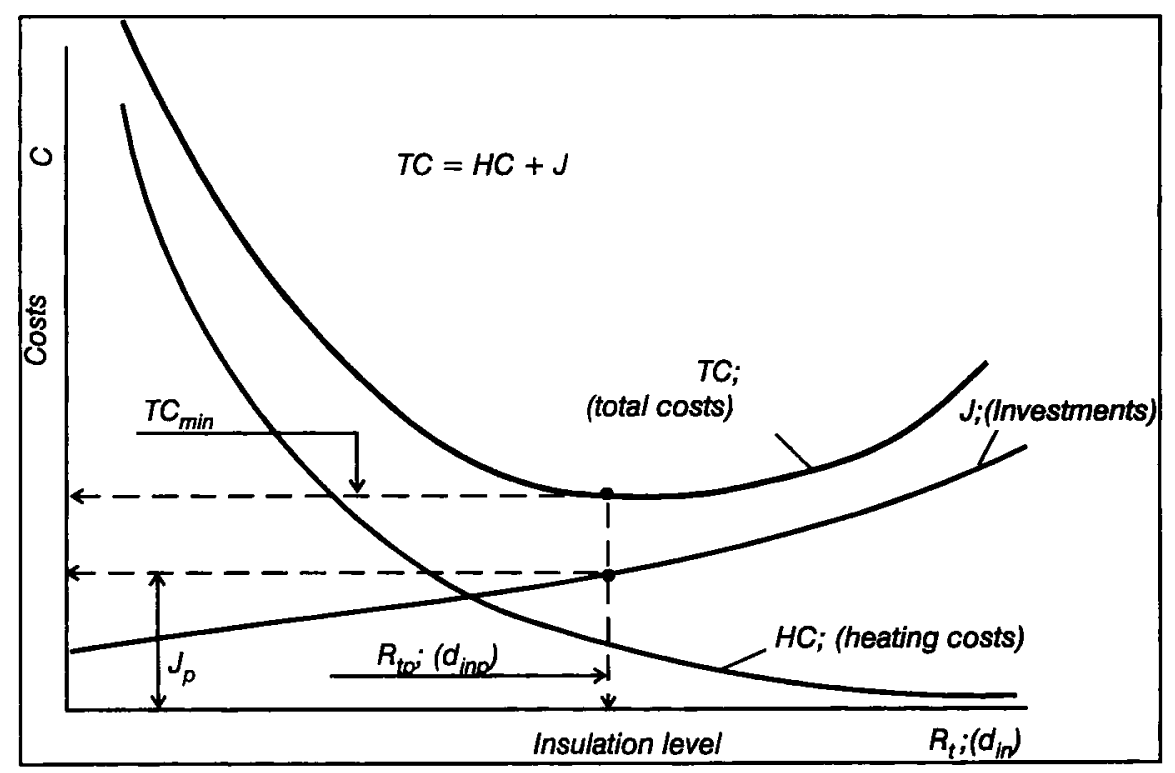

Fig 2. The dependence of expenses in regard to insulation level [optimum economical $R_{t p}\left(d_{\text {in.p }}\right), J_{p}$ ]

$$
B=\frac{1}{N^{\prime}}=\frac{r-e}{1-(1+e)^{N} /(1+r)^{N}} ; 1 / \text { a. }
$$

Then discounted life cycle (corresponding to the index of present value of heating cost during life cycle):

$$
N^{\prime}=\frac{1}{B}=\frac{1-[(1+e) /(1+r)]^{N}}{r-e} ; \quad \text { a. }
$$

The terms in expressions 5 and 6 are the following: $N$ - economical life cycle of insulation project for determination of life cycle cost LCC; $\boldsymbol{r}$ - real discount rate, as discount rate $\left(r_{n}\right)$ minus inflation rate $(i)$, excluding rise in heat price; $\boldsymbol{e}$ - real heat price rise rate, as heat price rise rate $\left(e_{n}\right)$ minus inflation rate $(i)$

Calculation is impossible at $e=r$. Then the assumptions are held that $e$ is approaching to the $r$ $(e \Leftrightarrow r)$ or $N^{\prime}=N$.

The investments $J, \mathrm{Lt} / \mathrm{m}^{2}$ for different values of thermal resistance $\boldsymbol{R}_{t}$, are to be known for successful solution of this task. The optimal economically value of thermal resistance at the selected insulation type would be at the least value of $A T C$.

If the dependence of investments $J$ due to thermal resistance of insulation layer $\boldsymbol{R}_{i n}$ is known or it can be estimated approximately, then:

$$
J=J_{0}+k_{\text {in }} \cdot d_{\text {in }}, \quad \mathrm{Lt} / \mathrm{m}^{2},
$$

and

$$
\begin{gathered}
d_{\text {in.p }}=\sqrt{\frac{\lambda_{d s, i n} \cdot \Delta \Theta \cdot t \cdot E \cdot N^{\prime}}{k_{i n}}}-R_{0} \cdot \lambda_{d . s, i n}, \mathrm{~m} ; \\
R_{\text {in.p }}=d_{\text {in.p }} / \lambda_{d s, i n}, \quad \mathrm{~m}^{2} \cdot \mathrm{K} / \mathrm{W} \\
R_{t . p}=R_{0}+R_{\text {in.p }}, \quad \mathrm{m}^{2} \cdot \mathrm{K} / \mathrm{W}
\end{gathered}
$$

and, finally, estimated heat transmission coefficient in $\mathrm{W} /\left(\mathrm{m}^{2} \cdot \mathrm{K}\right)$,

$$
U_{P}=1 / R_{t . p},
$$

In the expressions 7 to 11 the terms are used: $J_{0}$ initial insulation installation cost, $\mathrm{Lt} / \mathrm{m}^{2} ; d_{i n}$ - thickness of insulating layer, $\mathrm{m} ; \boldsymbol{k}_{\text {in }}$ - insulation cost, $\mathrm{Lt} / \mathrm{m}^{3} ; \boldsymbol{R}_{\boldsymbol{\theta}}$ the thermal resistance of all other layers of the considered construction, including film surfaces, $\mathrm{m}^{2} \cdot \mathrm{K} / \mathrm{W}$; $\lambda_{\text {d.s.in }}$ - design heat conductivity value of insulating material, $\mathrm{W} /(\mathrm{m} \cdot \mathrm{K})$.

If it is considered to insulate the existing building additionally, the decrease in heating costs is compared with the amount of investments supposed. If the insulation level of a new building is under consideration, the costs are compared with those for a building under necessary indoor and hygienic requirements.

If the economical conditions are not stable, the calculations ought to be provided at different time period $\boldsymbol{A D}$, estimating the most profitable level of insulation and its pay-back now or in future. 


\section{Conclusions}

1. The new edition of the Building Code would suit the EC requirements and provide a possibility to evaluate thermal properties of building materials, elements and whole buildings under the same conditions, as in EC.

2. The new edition of Building Code has slightly higher thermal requirements for dwelling houses than the existing document. Separate thermal requirements for public and industrial buildings with regard to ventilation and heat gains are also presented in it.

3. The suggested system of requirements provides more freedom for designers to achieve better results in energy saving.

\section{References}

1. RSN 143-92 Building Thermal Technique. Vilnius, 1994. $75 \mathrm{p}$.

2. Draft prEN $832: 1994 \mathrm{E}, 1994-10-D r a f t$ Standard. 45 p.

3. CEN/TC 89/ W 93 N 357E. 9 p.

İteikta 19980622

\section{ŠILUMOS NUOSTOLIU PASTATUOSE NORMAVIMAS}

\section{Stankevičius, J. Karbauskaitė}

Santrauka

Nauji reikalavimai pastatų šilumos izoliacijai Lietuvoje buvo patvirtinti jau $1992 \mathrm{~m}$. Naujajame reglamente "Pastatu atitvaru šiluminé technika" atitvarų normines šilumos perdavimo koeficientu vertés buvo pagrịstos energijos sąnaudy analize per tam tikrą pastato naudojimo laikotarpi, nustatant minimalias šiu sąnaudu vertes ịvairioms konstrukcijų rūšims. Atsižvelgiant $\mathfrak{i}$ šias sąnaudas, optimali gyvenamuju namy stogo atitvaros šilumos perdavimo koeficiento vertè būtų $0,18 \mathrm{~W} /\left(\mathrm{m}^{2} \cdot \mathrm{K}\right)$, išorinių sienu $0,26 \mathrm{~W} /\left(\mathrm{m}^{2} \cdot \mathrm{K}\right)$, langu ir dury - $1,9 \mathrm{~W} /\left(\mathrm{m}^{2} \cdot \mathrm{K}\right)$. Mažiausiai imlios energijai pasirodè skydines karkasinès konstrukcijos, labiausiai - masyvios, kurioms naudojamos keramzitbetonio plokštės. Gauti rezultatai labai panašūs i nusistovejusius atitvarų šilumos perdavimo reikalavimus Skandinavijos šalyse. Remiantis šiu tyrimu duomenimis, buvo parengti šilumos perdavimo per atitvaras norminiai reikalavimai atsižvelgiant i pastato paskirtị. Pvz., gyvenamụjų namų išorinių sienų šilumos perdavimo koeficiento norminè vertè $-0,26 \mathrm{~W} /\left(\mathrm{m}^{2} \cdot \mathrm{K}\right)$, viešosios paskirties pastatu $-0,30 \mathrm{~W} /\left(\mathrm{m}^{2} \cdot \mathrm{K}\right)$, pramones pastatu - 0,40 $\mathrm{W} /\left(\mathrm{m}^{2} \cdot \mathrm{K}\right)$; pataisa $\boldsymbol{\kappa}$ skirta ịvertinti palaikomą vidutinę temperatūrą patalpose. Be iprastinių atitvarų rūšių, t.y. stogụ, grindų, langu, išorinių sienų, šiose normose yra dar ilginių šiluminiu tilteliu sąvoka. Šilumos perdavimas per ilginius šiluminius tiltelius sudaro palyginti nemažą dalị pastato šilumos nuostoliu, ypač kai atitvaros turi gerą šiluminę izoliaciją, todèl bütina i tai atsižvelgti. Leistinosios atitvaru šilumos perdavimo koeficiento vertés remiasi higienos ir patalpų komforto reikalavimais. Kitas žingsnis buvo - nustatyti normines šilumos nuostoliy pastatuose vertes, kad būtu galima plačiau taikyti ịvairias atitvarines konstrukcijas, nevaržant architektu ir projektuotojų, bet išvengiant nesaikingo energijos suvartojimo pastatuose. Pastato atitvaros turi atitikti šilumos perdavimo koeficiento leistinus reikalavimus, o pastato savitieji šilumos nuostoliai turi neviršyti ribinių verčių, apibrežiamu norminemis šilumos perdavimo koeficiento vertemis, t.y. dalis atitvaru dèl kokių nors sumetimu gali tureti blogesnes šilumines savybes (iki tam tikros leistinos ribos), tą kompensuojant kitose vietose, tačiau savitieji viso pastato šilumos nuostoliai dèl šilumos perdavimo per atitvaras turi neviršyti norminių. Griežčiausi reikalavimai skirti gyvenamiesiems namams - pirmiausiai dèl to, kad jie sudaro didžiausią namų dalị, juose būtina užtikrinti reikiamas pastovias higienos sąlygas, ir energijos taupymas juose, sumažinant temperatūrą naktị ar savaitgaliais, yra labiau ribotas, palyginti su kitais, viešosios paskirties ar pramonès pastatais. Šis naujai sudaromas statybos reglamentas atitinka ir Europos Bendrijos pagrindines nuostatas pastaty šilumos nuostolių apribojimo atžvilgiu. Pastatų rekonstrukcijos atveju atitvarų šilumos izoliacijos storis ịvertinamas pagal ekonomines sąlygas, kad apsimokètụ idedamos léšos. Atsižvelgiama i paskolos grąžinimo terminus, palūkanų, infliacijos dydị, energijos brangimą ir pradines medžiagu kainas. Siūloma apskaičiuoti pasirinkty atitvaru optimalią šiluminę varžą ir išsirinkti mažiausią iš ju pagal pateikiamas priklausomybes. Paprastesniu atveju, jei galima pripažinti, kad šilumos izoliacijos kaina turi tiesinę priklausomybę nuo storio, galima remtis tiesioginiu optimalaus šilumos izoliacijos storio apskaičiavimu.

Vytautas STANKEVIČIUS. Doctor Habil, Professor. Institute of Architecture and Construction, Tunelio 60, Kaunas LT-3035, Lithuania

Head of Building Thermal Physics Laboratory, Chairman of Scientific Council at the Institute of Architecture and Construction, Chairman of Qualitative Commission for Architecture and Civil Engineering at Kaunas Technology University, Member of Lithuanian Fund of Science and Studies, Member of the Editorial Board of Journal "Civil Engineering", Member of ABOK (Russian Association of Heating, Ventilating and Air Conditioning Engineers), Expert member of Lithuanian Academy of Sciences, Coordinator for Lithuania at the CIB in the field of Building Thermal Physics. Author and co-author of more than 180 reports and papers, including 4 inventions, 1 monograph and 1 study guide, manager of working groups for 12 Building Codes. Research interests: energy saving in buildings, weather durability of external wall layers, heat and mass transfer in building constructions.

Jūratė KARBAUSKAITE். Doctor. Institute of Architecture and Construction, Building Thermal Physics Laboratory. Tunelio 60, 3035 Kaunas, Lithuania.

Member of ABOK (Russian Association of Heating, Ventilating and Air Conditioning Engineers), Member of TG28 (Joint CIB-ISIAQ Task Group), Member of LITESI (Lithuanian Association of Heating, Ventilating and Air Conditioning Engineers). Author and co-author of more than 50 reports and papers, including 2 Building Codes. Research interests: energy saving in buildings, heat and mass transfer in building constructions, indoor climate. 